\title{
Overview of Multi-kilowatt Free-Piston Stirling Power Conversion Research at GRC
}

\author{
Steven M. Geng ${ }^{1}$, Lee S. Mason ${ }^{1}$, Rodger W. Dyson ${ }^{1}$, and L. Barry Penswick ${ }^{2}$ \\ ${ }^{1}$ Thermal Energy Conversion Branch, NASA Glenn Research Center \\ 21000 Brookpark Rd., Cleveland, OH 44135, USA \\ ${ }^{2}$ SEST Inc., 18000 Jefferson Park, Middleburg Hts, OH 44130, USA \\ ${ }^{1}$ (216) 433-6145, Steven.M.Geng@nasa.gov
}

\begin{abstract}
As a step towards development of Stirling power conversion for potential use in Fission Surface Power (FSP) systems, a pair of commercially available $1 \mathrm{~kW}$ class free-piston Stirling convertors and a pair of commercially available pressure wave generators (which will be plumbed together to create a high power Stirling linear alternator test rig) have been procured for in-house testing at Glenn Research Center. Delivery of both the Stirling convertors and the linear alternator test rig is expected by October, 2007. The $1 \mathrm{~kW}$ class free-piston Stirling convertors will be tested at GRC to map and verify performance. The convertors will later be modified to operate with a NaK liquid metal pumped loop for thermal energy input. The high power linear alternator test rig will be used to map and verify high power Stirling linear alternator performance and to develop power management and distribution (PMAD) methods and techniques. This paper provides an overview of the multi-kilowatt free-piston Stirling power conversion work being performed at GRC.
\end{abstract}

Glenn Research Center 


\title{
Overview of Multi-Kilowatt Free-Piston Stirling Power Conversion at GRC
}

\author{
By: \\ Steven M. Geng, Lee S. Mason, and Rodger W. Dyson \\ NASA Glenn Research Center \\ and \\ L. Barry Penswick \\ SEST, Inc.
}

Presented to:

The Space Technology and Applications International Forum (STAIF-2008)

Albuquerque, New Mexico

February $10-14,2008$ 


\section{Agenda}

- Introduction

- Multi-kW Stirling Technology Development

- 1 kWe Stirling Convertors

- Performance Map Test

- NaK Heat Exchanger

- High Power Linear Alternator Test Rig

- Convertor Scale-up

- System Technology Demo Unit (TDU)

- Concluding Remarks

- Acknowledgements 


\section{Introduction}

- Free-Piston Stirling power conversion is an option for Fission Surface Power systems

- Stirling convertors well suited for use with low temperature $(<900 \mathrm{~K})$ reactors

- Low development risk

- Terrestrial-derived reactor technology

- Conventional materials

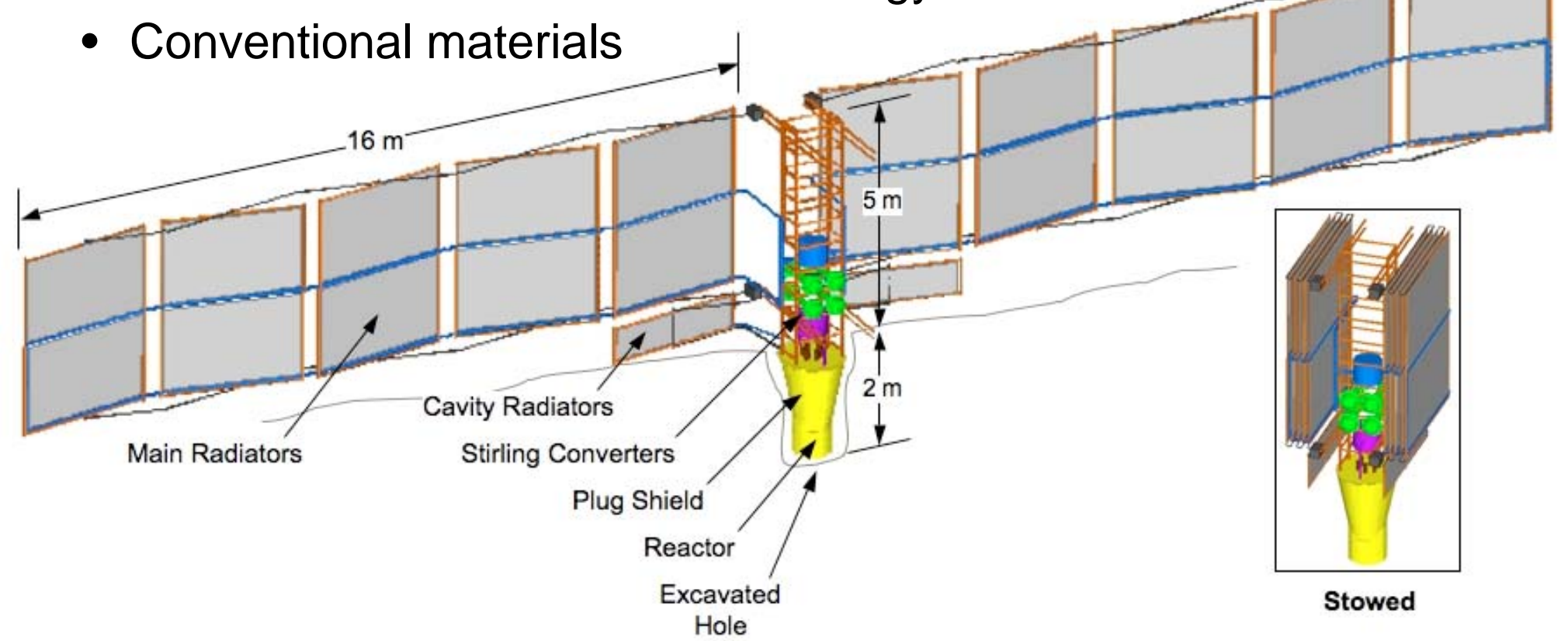




\section{Introduction}

- Reference Concept System Schematic

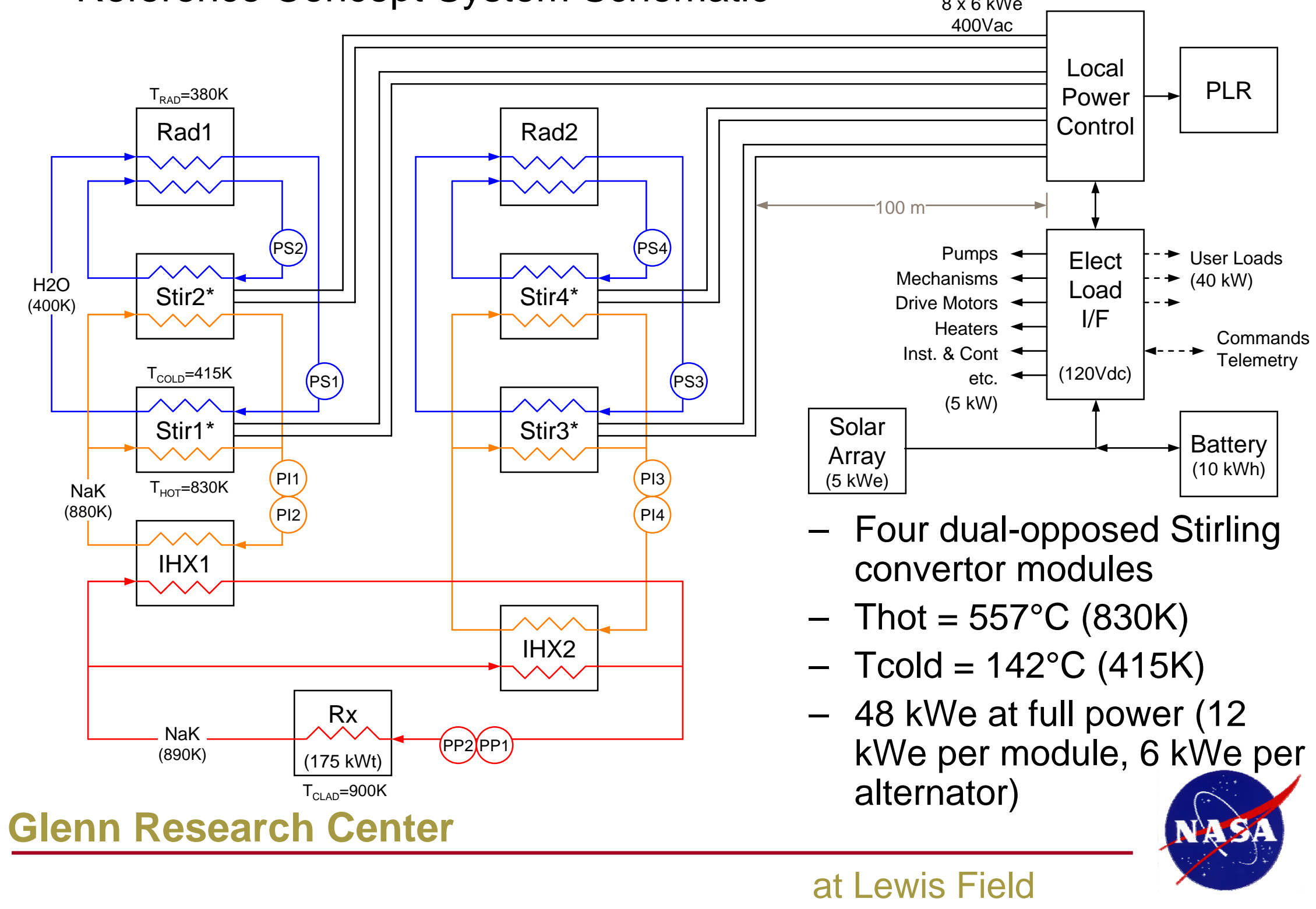




\section{Multi-kW Stirling Technology Development}

- Liquid metal loop integration

- Procure 1 kWe convertors

- Develop NaK heat exchanger

- Test at MSFC

- Alternator/PMAD integration

- Procure High Power Linear Alternator Test Rig (HPLATR) (5 kWe LAs)

- Develop PMAD techniques to convert AC output of Stirling for typical loads

- Convertor Scale-up

- 5 kWe (FM, Auburn, and GRC)

- Design lineage to '80s convertors built by MTI (SPDE/SPRE and CTPC)

- Technology Demonstration Unit (TDU)

- Full-scale power conversion unit coupled to a liquid metal reactor simulator and radiator in thermal vacuum 


\section{Multi-kW Stirling Technology Development}

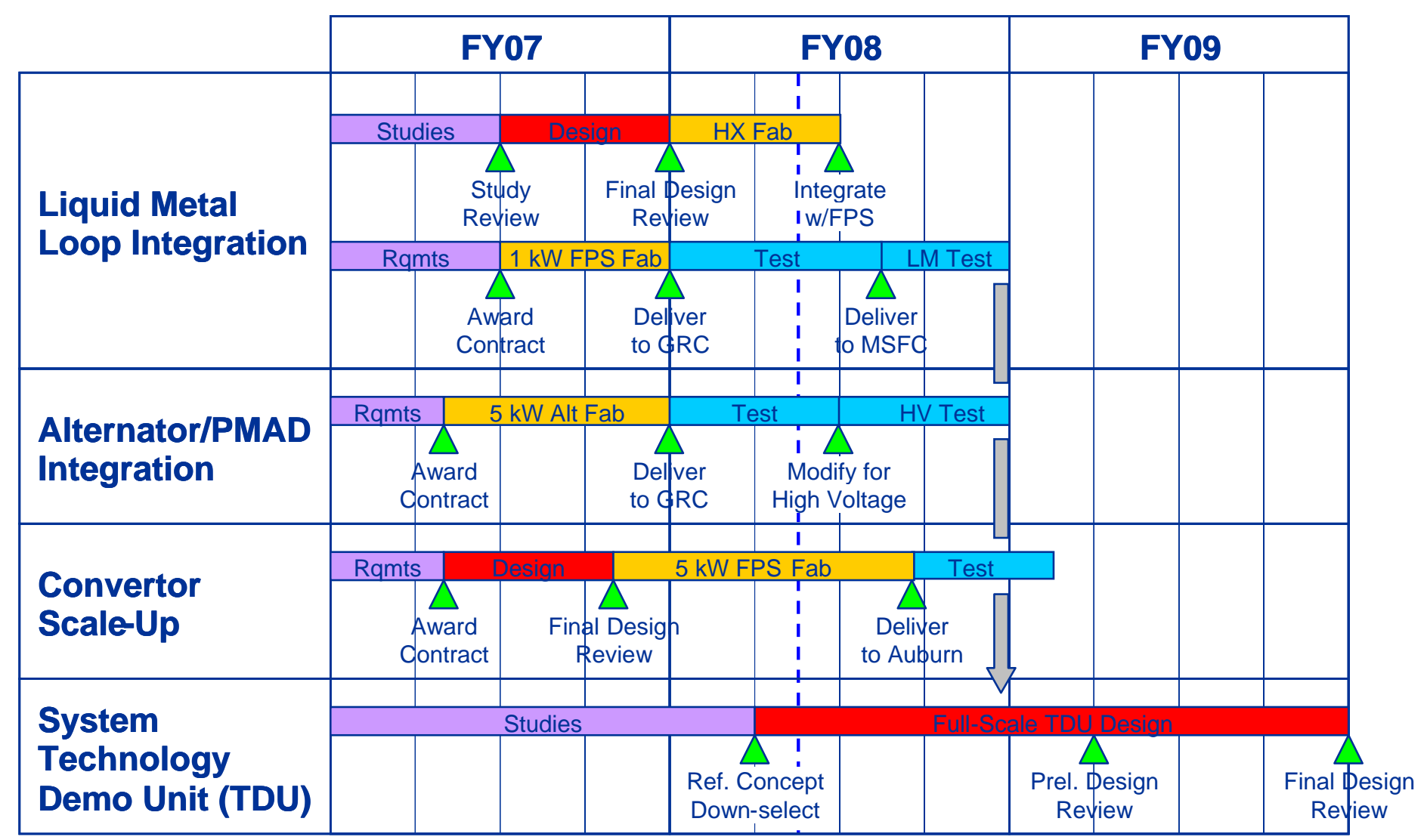




\section{1 kWe Free-Piston Stirling Convertors}

- Pair of P2A (EG-1000) convertors purchased from Sunpower

- 100,000 Hr Design Life

- Thot: $550^{\circ} \mathrm{C}$

- Tcold: $50^{\circ} \mathrm{C}$

- Gas: Helium

- Pressure: 3.0 MPa (435psi)

- Frequency: $50 \mathrm{~Hz}$

- Nominal Output Power: 1.1 kWe

- Convertor Efficiency: 31\%

- Mass: $35 \mathrm{~kg}$

- Over 100 units have been built

- Commercial units designed for utility grid in Europe

- Design not driven by low mass, high efficiency or high frequency Glenn Research Center

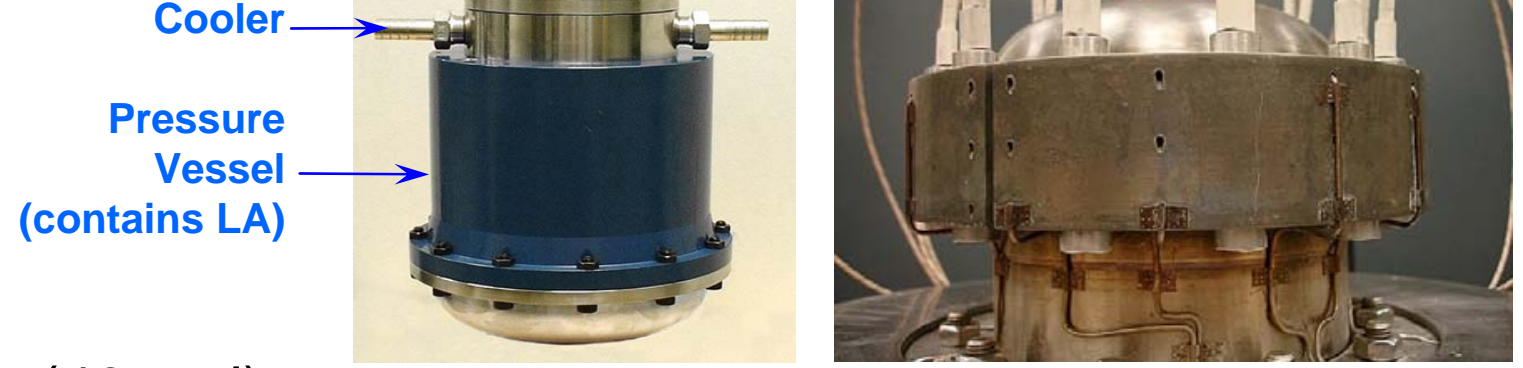

Top Two Photos Courtesy of Sunpower, Inc.
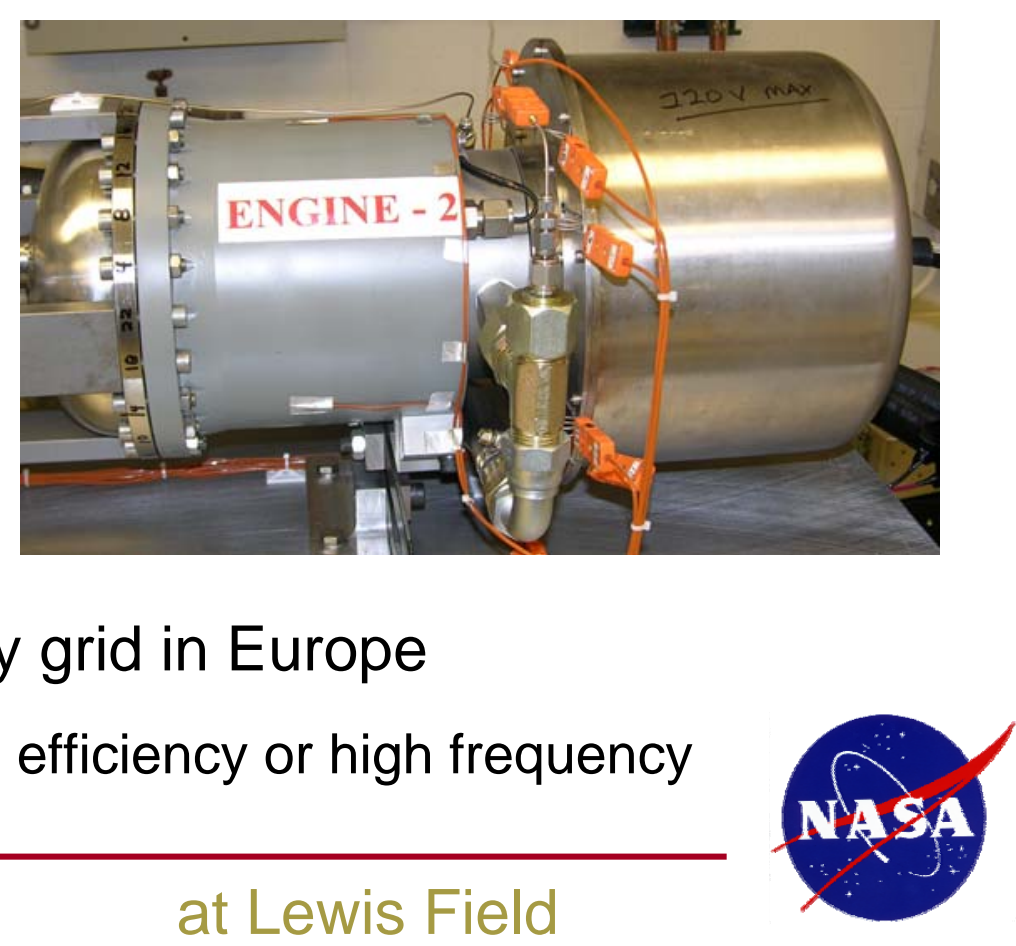


\section{1 kWe Free-Piston Stirling Convertors}

- Performance Map Testing
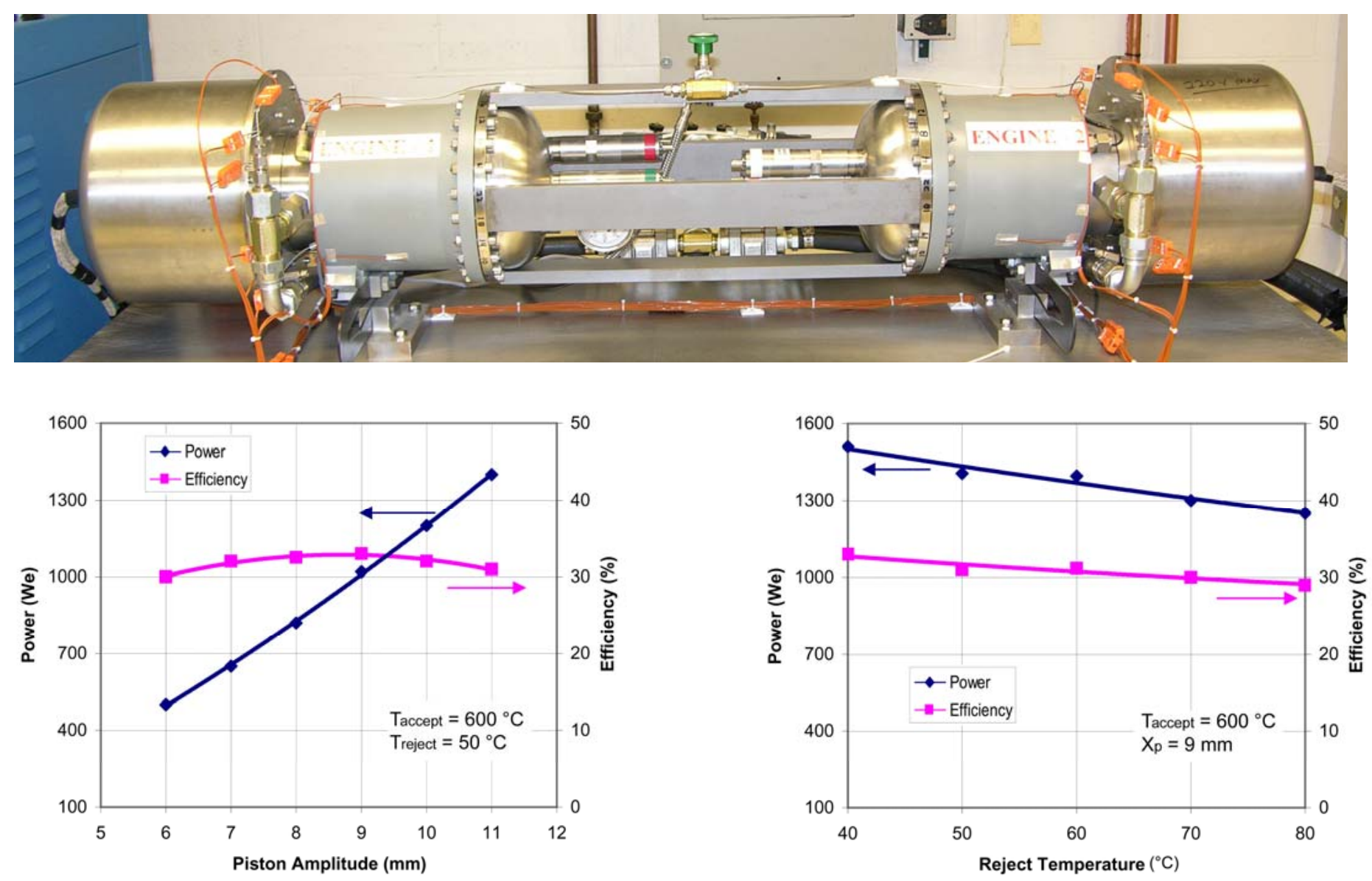

Plots Courtesy of Sunpower, Inc.

Glenn Research Center 


\section{1 kWe Free-Piston Stirling Convertors}

- P2A convertors in GRC test cell

- Variacs supply power to convertors (12 cartridge heaters per convertor)

- Synchronized Chroma AC Sources used to control piston amplitude and frequency

- Data acquisition system monitors temperatures, pressure, piston amplitudes, vibration level, and voltages

- Performance Map

- Thot: $450-550^{\circ} \mathrm{C}$

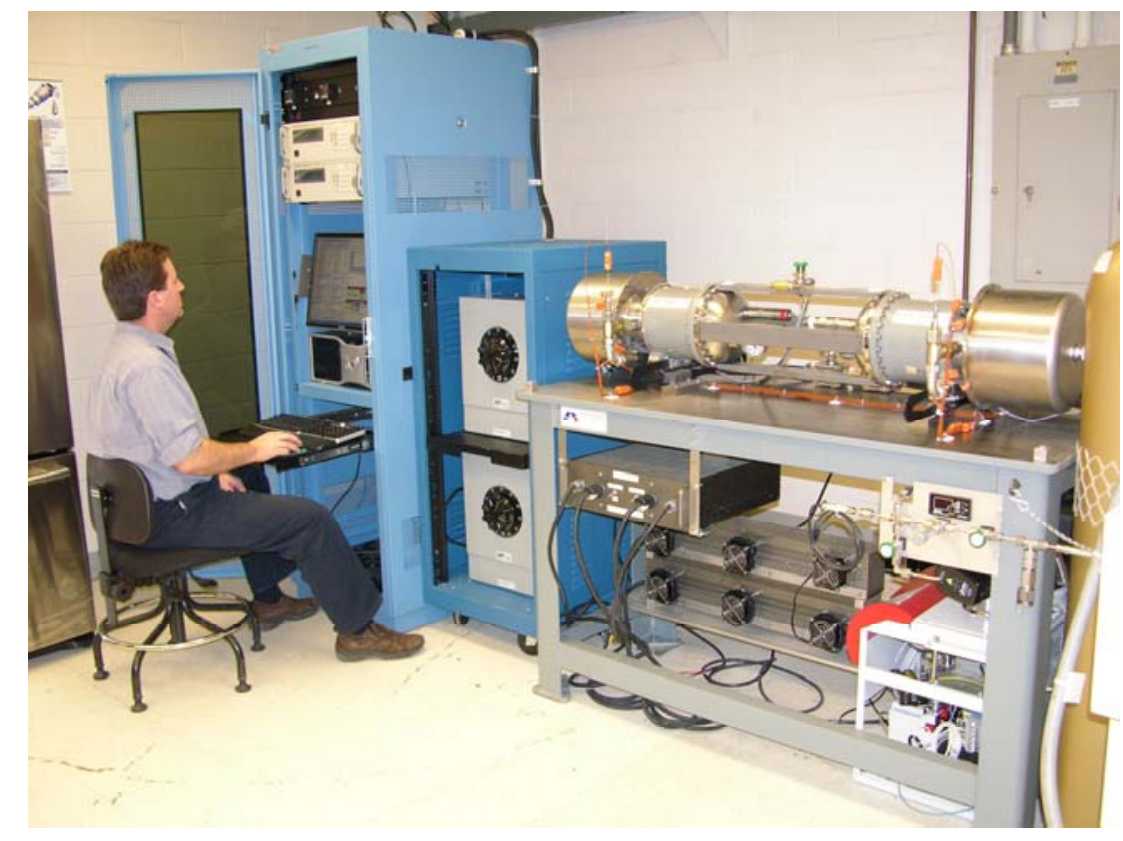

- Tcold: $30-70^{\circ} \mathrm{C}$

- Piston Amp: 6 - 11mm 


\section{1 kWe Free-Piston Stirling Convertors}

NaK Heat Exchanger/P2A Heater Head Design

- Trade-space included various mechanical configurations in addition to test facility operating characteristics

- Materials with proven track record (316 SS)

- Joining techniques (welding)

- Acceptable NaK flow velocities

- CFD analyses used to evaluate candidate designs

- Includes effects of gravity, inlet flow distortion, and pressure drop

- Two NaK heat exchangers/P2A heater heads are currently being fabricated

- Plan to test P2A convertors in MSFC's pumped NaK loop test facility in 2008

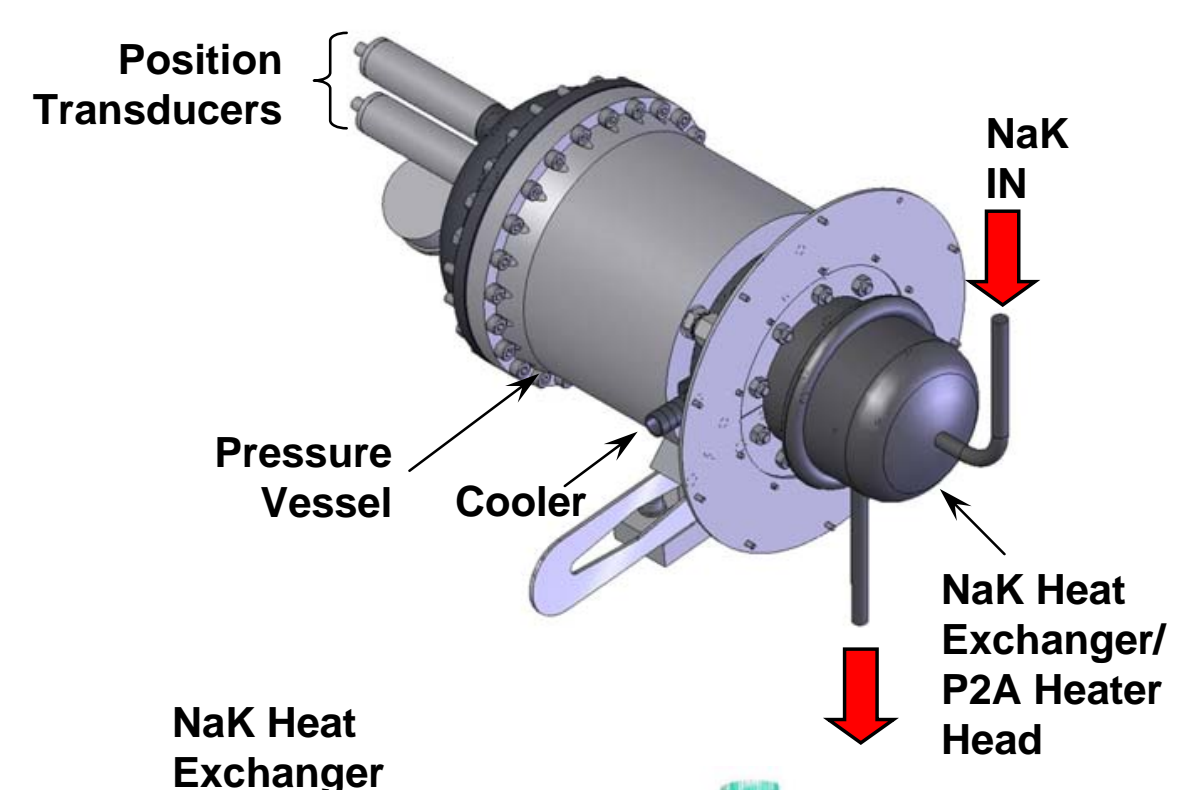




\section{High Power Linear Alternator Test Rig}

- Pair of modified 2S297W pressure wave generators (PWGs) purchased from Clever Fellows Innovation Consortium (CFIC)

- Gas: Helium

- Pressure: 4.0 MPa (580psi)

- Frequency: $102 \mathrm{~Hz}$

- Nominal Output Voltage: 330 Vac

- Nominal Motor Input Power: 10 kW

- Motor Efficiency: 90\%

- Mass: $35 \mathrm{~kg}$

- HPLATR will be used to develop PMAD techniques applicable to FSP
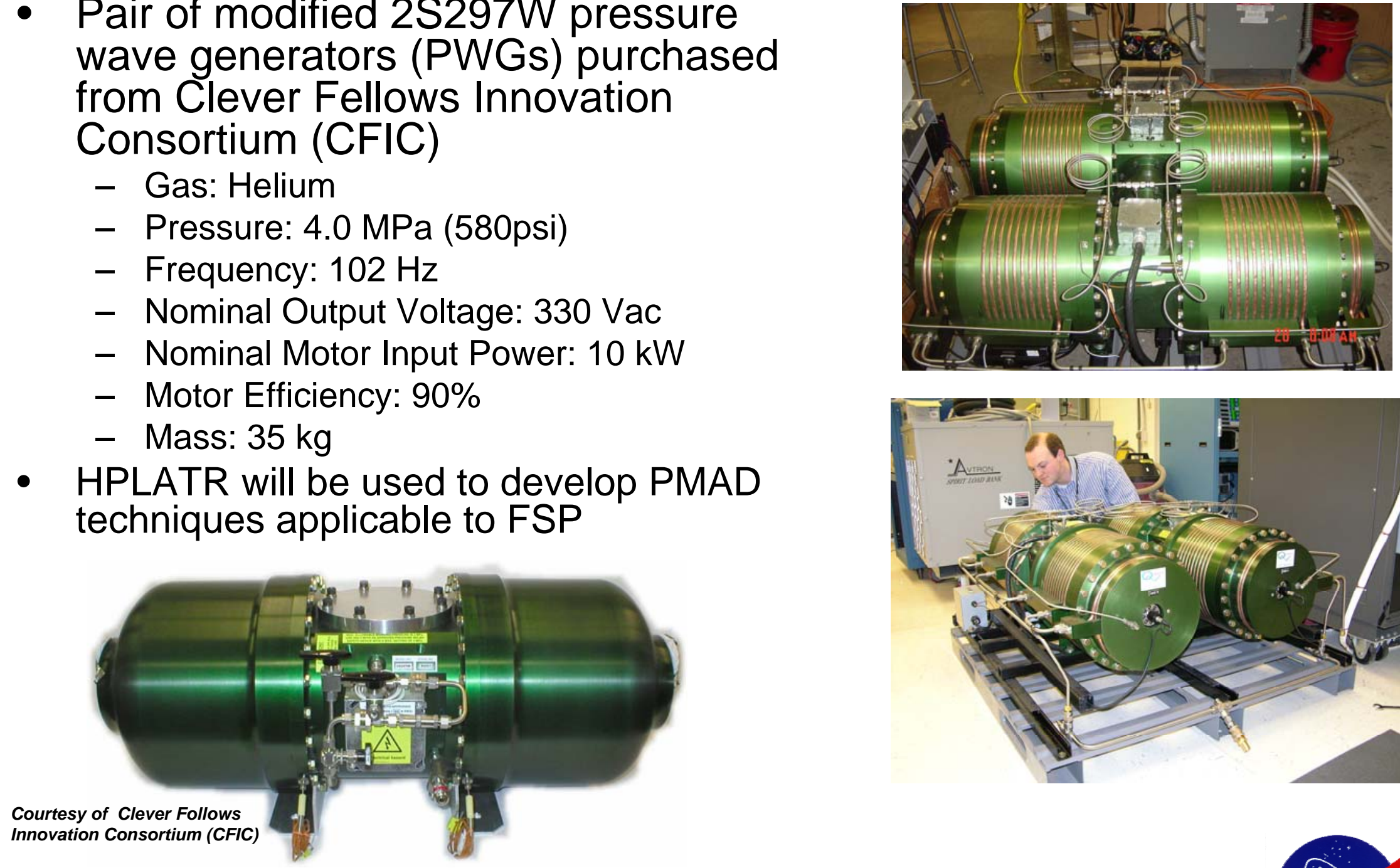

\section{Glenn Research Center}

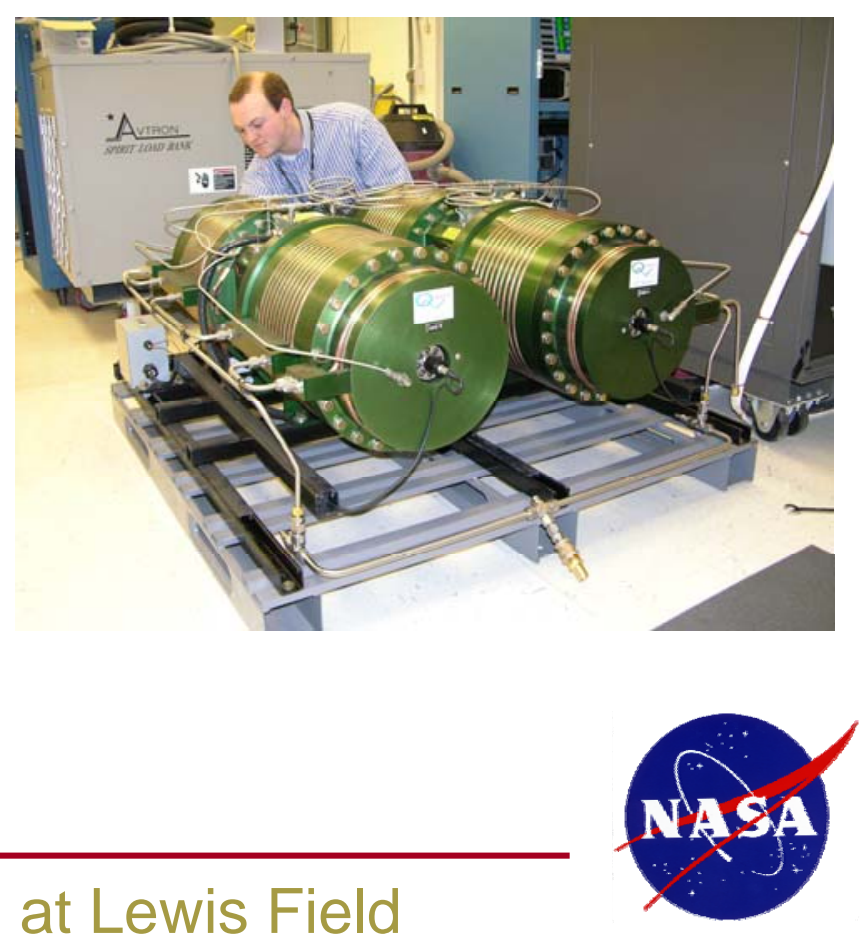




\section{High Power Linear Alternator Test Rig}

- Schematic of pressure wave generators configured as HPLATR

- Consists of four $5 \mathrm{kWe}$ linear motors/alternators

- No wearing parts (long-life, no maintenance)

Drive Motors

Linear

Alternators

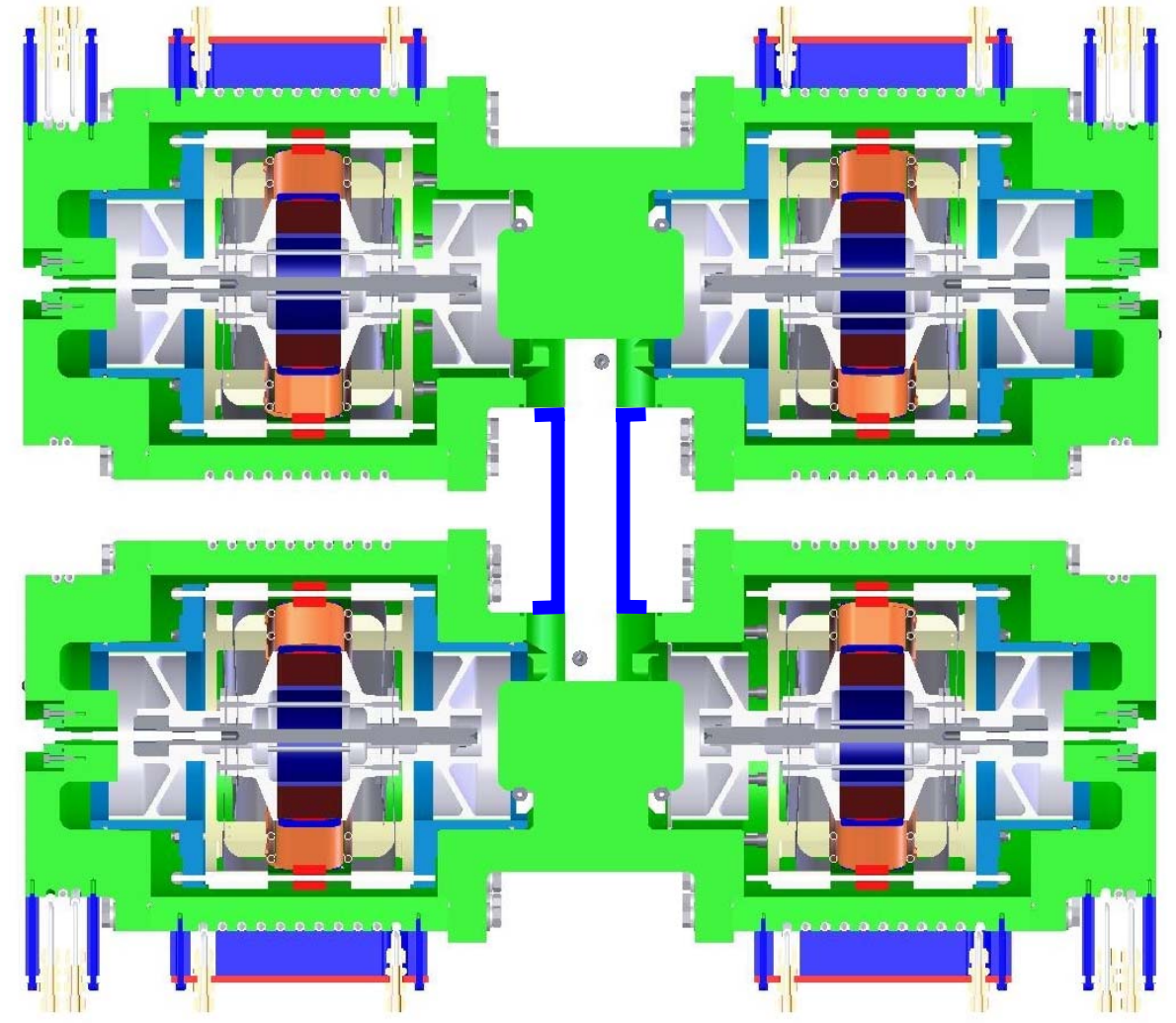

PWG 1

Courtesy of Clever Follows Innovation Consortium (CFIC) 


\section{Convertor Scale-up}

- Sub-contract was awarded to Foster-Miller (via Auburn) on 2-1-07 to design, build, and test a multi-kWe Stirling power convertor

- FM Approach: scale down highly successful SPDE/SPRE/CTPC $12.5 \mathrm{kWe}$ convertor design

- Exception: CFIC STAR linear alternator substitution

- Convertor components currently being fabricated

- Delivery to Auburn expected by June, 2008 Glenn Research Center
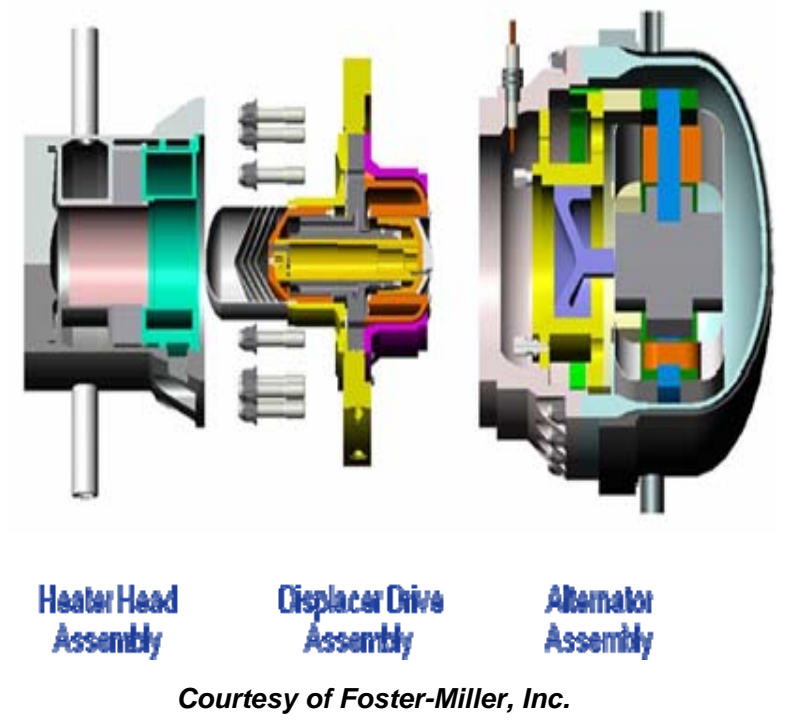

- Operating conditions

- Thot: $377^{\circ} \mathrm{C}(650 \mathrm{~K})$

- Tcold: $52^{\circ} \mathrm{C}(325 \mathrm{~K})$

- Power: 5 kWe, Peak 6 kWe

- Design Life: 5 years

- Working Fluid: Helium

- Pressure: $15 \mathrm{MPa}(2,175 \mathrm{psi})$

- Frequency: $85 \mathrm{~Hz}$ 


\section{Technology Demonstration Unit}

Notional TDU Test Layout in GRC Vacuum Facility \#6

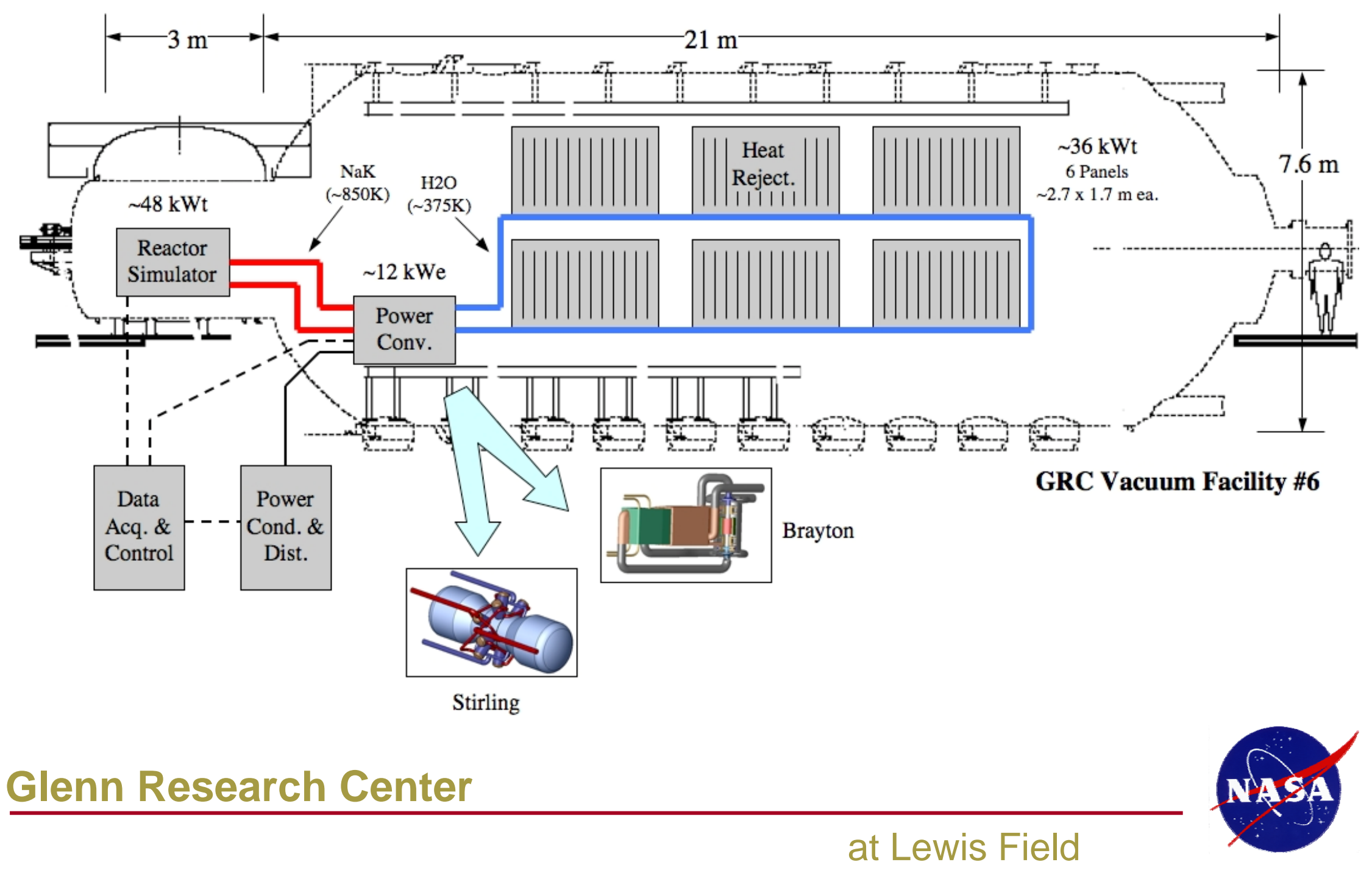




\section{Concluding Remarks}

- A pair of $1 \mathrm{kWe}$ free-piston Stirling convertors are being readied for performance map testing

- Two NaK heat exchanger/heater heads are being fabricated

- The NaK heat exchanger/heater heads will be installed on the 1 kWe Stirling convertors, then tested in the MSFC pumped NaK loop test facility later this year

- The HPLATR is being readied for operation to aid the development of PMAD techniques for surface power applications

- Stirling technology is a viable option for FSP applications 


\section{Acknowledgments}

- Malcolm Robbie of the Analex Corp developed the mechanical design of the NaK heat exchanger.

- The authors wish to thank Sunpower Inc., Clever Fellows Innovation Consortium (CFIC) Inc., Auburn Space Research Institute, and Foster-Miller for contributing some of the information contained in this presentation.

- The work described in this presentation was performed for the Fission Surface Power Project within the Exploration Technology Development Program under the NASA Exploration Systems Mission Directorate. Any opinions expressed are those of the authors and do not necessarily reflect the views of the Exploration Systems Mission Directorate. 